\title{
The effect of early versus delayed surgical debridement on the outcome of open long bone fractures at Bugando Medical Centre, Mwanza, Tanzania
}

Njee Nobert ${ }^{1,2 \dagger}$, Nyambura Moremi ${ }^{3 \dagger}$, Jeremiah Seni ${ }^{3^{*}+}$, Ramesh M. Dass ${ }^{1,2}$, Isdori H. Ngayomela ${ }^{1,2}$, Stephen E. Mshana ${ }^{3}$ and Japhet M. Gilyoma ${ }^{1,2}$

\begin{abstract}
Background: Urgent surgical debridement of open long bone fractures is of paramount importance for prevention of subsequent infection. Due to limited information on the timing of this surgical procedure in Mwanza, Tanzania; the present study was conducted to evaluate the effect of early versus delayed surgical debridement on the outcome of open long bone fractures.

Methods: A prospective cohort study involving 143 patients with open long bone fractures admitted at Bugando Medical Centre (BMC) between December 2014 and April 2015 was conducted. Patients were stratified into two main groups basing on whether they presented at BMC and operated early (within 6 h) or late (more than $6 \mathrm{~h}$ ). Socio-demographic and clinical information were collected using structured questionnaire. Analysis was done using STATA software version 11.

Results: The male to female ratio was 1.6: 1, with most of the patients being in their third decade of life (30.8\%). Road traffic accident (RTA) was the most common cause of fractures (67.8\%). Majority of patients, 91 (63.6\%) had Gustillo-Anderson grade II and the timing of debridement was significantly associated with this grading ( $p$-value $=0.05)$. Nine $(6.3 \%)$ patients developed surgical site infection (SSI) and the median length of hospital stay (LOS) (interquartile range) was 7 (5-10) days, ranging from 3 to 35 days. SSI was found more in the late group compared to the early group [7.5 \% (6/80) versus $4.8 \%(3 / 63)$ respectively, $p$-value $=0.503)]$ and LOS was also longer in the late group compared to the early group [7 (6-11.5) days and $6(5-10)$ days respectively, $p$-value $=0.06]$. Pseudomonas aeruginosa was the predominant bacteria causing SSI.

Conclusions: Open long bone fracture injuries due to RTA are common at BMC. The risk of developing SSI in this setting is low and comparable to many other countries. Despite the fact that there was no statistical significant difference between early versus delayed debrided groups on SSI and LOS stays; the need for prompt surgical intervention in both groups should be an enduring focus to maintain these favorable outcomes.
\end{abstract}

Keywords: Open fractures, Surgical debridement, Outcomes, Mwanza

\footnotetext{
* Correspondence: senijj80@gmail.com

${ }^{\dagger}$ Equal contributors

${ }^{3}$ Department of Microbiology and Immunology, Catholic University of Health

and Allied Sciences, P.O.Box 1464, Mwanza, Tanzania

Full list of author information is available at the end of the article
} 


\section{Background}

The growing burden of open fractures is apparently of global concern and contribute significantly to high morbidity and long-term disabilities [1-4]. It is estimated that the annual incidence of open fractures is 11.5 per 100000 persons with preponderance of lower extremities [1]. In Tanzania and other countries in Sub Saharan Africa, the burden of open fractures has a long historical background but is currently escalating due to legalization of motor cycles as a means of public transport [2, 5-7]. Moreover, the negative health impact related to open fractures due to road traffic accidents (RTA) are many ranging from increased hospital admissions in the intensive care unit, infections, longer duration of hospital stays, long term disabilities and deaths $[2,8,9]$.

In the light of the increase in the trends of open fractures in Tanzania, there is an obvious need to revisit the existing management guidelines so as to ensure better outcomes among patients involved. Despite the fact that there are advances in technological innovations on the management of open fractures compared to conventional management modalities, there are still numerous challenges especially in developing countries [10-13]. The long debated optimal timing of surgical debridement basing on the " $6 \mathrm{~h}$ rule" still remain to be controversy as some studies support it whereas others refute it to be associated with plausible outcome in terms of less incidences of surgical site infections and shorter LOS [13-20].

Therefore, the present study intended to establish evidence based and locally generated information on the effect of timing of surgical debridement as stipulated in the " $6 \mathrm{~h}$ rule" on the outcome of patients with long open bone fractures at Bugando Medical Centre (BMC).

\section{Methods}

\section{Study area, design and sampling procedures}

This was a prospective cohort study conducted between December 2014 and April 2015 at accident \& emergency department and orthopedic \& traumatology wards at BMC which is a tertiary, consultant and teaching hospital serving over 13 million people in the Lake Victoria region - North-western Tanzania. The study involved all patients with open long bone fractures admitted at BMC who voluntarily consented to participate in the study and subsequently underwent surgical debridement in the operating theatres. The study excluded patients with open long bone fractures and other life-threatening injuries such as head, chest, or abdominal injuries as these would be the priority groups in terms of management over any limb-threatening injury as well as patients with overt clinical signs of infections. The sample size of 148 patients was calculated using Kirkwood and Sterne (2003) at $5 \%$ significance level, power of $90 \%$ and based on the proportion of $11.6 \%$ from a previous study [18].
Convenience sampling of patients who meet the inclusion criteria was performed until the sample size was reached.

\section{Patients' management and data collection}

Patients were informed about the study and requested to voluntarily participate. A structured questionnaire was administered which in turn stratified them into two main groups basing on whether they presented at $\mathrm{BMC}$ and operated early (within $6 \mathrm{~h}$ ) or late (more than $6 \mathrm{~h}$ ). All patients were managed according to BMC management protocol on open long bone fractures which included Advanced Trauma Life Support, urgent baseline investigations (Hemoglobin estimation, blood grouping and cross matching); radiological tests ( $\mathrm{x}$-rays of the affected bone); provision of systemic antibiotic prophylaxis (Ceftriaxone and Metronidazole) and anti tetanus prophylaxis; grading of open long fracture according to Gustilo-Anderson classification system [10]; surgical debridement in the theatre followed by fracture stabilization by Plaster of Paris cast (POP), external fixation and open reduction and internal fixation (ORIF), and early soft-tissue coverage whenever required.

In the ward, the provider initiated counselling and testing for HIV serological tests was performed according to the National Guideline [21]. Patients were followed up to assess the SSI incidences. SSI was defined as previously described as the presence infection which occurs within 30 days after the operation evidenced by purulent discharge from the site, isolation of bacterial pathogen(s) and at least one of the following signs or symptoms of infection namely pain or tenderness, localized swelling, redness, or heat [22]. For patients who developed SSI, a swab with Stuart's Transport media (Improswab ${ }^{\circ}$, Shanghai, China) was used to collect pus specimen basing on the standard guidelines and transported to the Catholic University of Health and Allied Sciences (CUHAS) Multipurpose Laboratory within an hour of collection to be analyzed. In the laboratory, the specimens were registered in the log book and processed based on standard microbiological procedures namely Gram stain, culture on Blood agar and MacConkey agar (HI Media, India) followed by biochemical identification tests according to the previously described methods [23]. The bacterial isolates were subjected to the antimicrobial susceptibility testing according to the Clinical Laboratory Standard Institute [24]. Patients were followed for 30 days to assess the incidence of SSI weekly during wound dressing and LOS in the two groups of patients [22].

\section{Data collection and analysis}

Sociodemographic, clinical and laboratory data were collected using a structured questionnaire, transferred to 
Excel for consistence checks and analyzed using STATA version 11 according to the objectives of the study. Continuous variables were summarized using proportions and frequencies; and depending on the distribution of data, mean \pm standard deviation or median (interquartile range) for continuous variable were used. Chi-square or Fischer's exact tests was used to assess the distribution of data and p-value of less than 0.05 was used as a cuff off point for showing the significant association between predictor variables and outcome among patients with open long bone fractures. The main primary outcomes were occurrence of SSI and LOS.

\section{Ethical considerations}

The approval to carry out this study was sought from the joint CUHAS/BMC Research, Ethics and publication committee. Voluntary written informed consent was sought from every participants prior to be involved into the study. Patient's refusal to consent or withdraw from the study did not alter or jeopardize their access to standard medical care at BMC. Confidentiality was ensured by using anonymous codes. For patients who developed SSI, results for antimicrobial susceptibility testing was promptly given to the attending doctor for specific management.

\section{Results}

During the study period, a total number of 148 patients with open long bone fractures were managed at BMC. Of these, 5 patients were excluded from the study due to failure to meet the inclusion criteria (Fig. 1).
Baseline socio-demographic and clinical characteristics of patients

The median age (IQR) of patients was 34 years (25-42 years), ranging from 11 to 87 years with the peak age between 31 and 40 years in approximately $30.8 \%$ of participants. Majority of participants were males, 89 $(62.2 \%)$; with primary and secondary school education, 114 (79.7\%); peasants, 48 (33.5\%); and their open fractures were due to RTA 96 (67.1\%). Out of the143 patients, nine $(6.3 \%)$ were found to be HIV seropositive (Table 1).

\section{Distribution of fracture characteristics among patients with open long bone fracture}

The tibia was the most common site of open fracture affecting $46.1 \%$ of patients and majority, 91 (63.6\%) had Gustilo-Anderson grade II. The distal third and mid-shaft were the most frequent location of fracture accounting for 40.6 and $39.9 \%$ of patients respectively and the most common fracture pattern was transverse in about $39.9 \%$ (Table 2).

\section{Treatment characteristics}

Regarding timing of surgical debridement, 80 (55.9 \%) patients had surgical debridement done $6 \mathrm{~h}$ post injury. The majority of surgical debridement, 138 (96.5\%) were performed by residents/medical officers and 5 (3.5\%) surgical debridement were performed by specialists.

Plaster of Paris (POP) was the most common method of skeletal stabilization performed in 70 (49.0\%) patients. This was followed by external fixator, skeletal

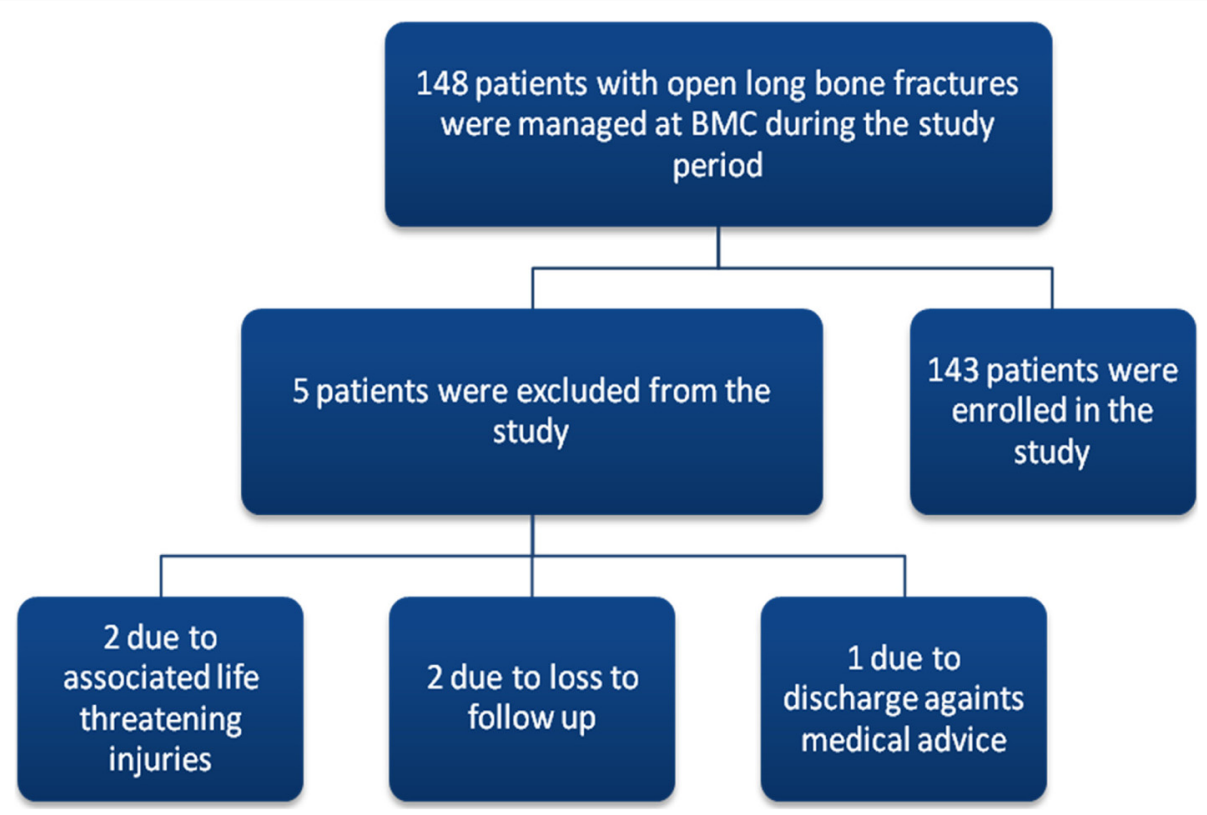

Fig. 1 Flow chart showing enrollment process of study participants. $B M C=$ Bugando Medical Centre 
Table 1 Baseline socio-demographic and clinical characteristics of patients with open long bone fractures

\begin{tabular}{|c|c|c|}
\hline Socio-demographic and clinical characteristics & Number & Percentage \\
\hline \multicolumn{3}{|l|}{ Sex } \\
\hline Male & 89 & 62.2 \\
\hline Female & 54 & 37.8 \\
\hline \multicolumn{3}{|l|}{ Education } \\
\hline Tertiary education & 18 & 12.6 \\
\hline Primary or secondary education & 114 & 79.7 \\
\hline No formal education & 11 & 7.7 \\
\hline \multicolumn{3}{|l|}{ Occupation } \\
\hline Students & 18 & 12.6 \\
\hline Peasants & 48 & 33.6 \\
\hline Driver & 3 & 2.1 \\
\hline Motorcycle rider & 19 & 13.3 \\
\hline Civil servants & 19 & 13.3 \\
\hline Businessman/woman & 34 & 23.8 \\
\hline Others & 2 & 1.4 \\
\hline \multicolumn{3}{|l|}{ Cause of injury } \\
\hline Road traffic accident & 97 & 67.8 \\
\hline Falls & 22 & 15.4 \\
\hline Assaults & 20 & 14.0 \\
\hline Others & 4 & 2.8 \\
\hline \multicolumn{3}{|l|}{ Place of injury } \\
\hline Along the road & 96 & 67.1 \\
\hline Residential areas (outside the house) & 23 & 16.1 \\
\hline Home (within the house) & 18 & 12.6 \\
\hline School & 3 & 2.1 \\
\hline Other places & 3 & 2.1 \\
\hline \multicolumn{3}{|l|}{ HIV serostatus } \\
\hline Seropositive & 9 & 6.3 \\
\hline Seronegative & 134 & 93.7 \\
\hline
\end{tabular}

traction and ORIF in 35 (24.5\%), 28 (19.6\%) and 9 $(6.3 \%)$ patients respectively. One $(0.3 \%)$ patient underwent limb amputation.

\section{Association of early versus delayed debridement with variables}

There was no statistical association between sociodemographic and clinical characteristics of patients with the timing of surgical debridement. However, there was a significant association between Gustilo -Anderson grade and the timing of surgical debridement with majority of patients falling in Grade II [92 (63.3\%)] and of these $52.4 \%(33 / 63)$ and $73.8 \%(59 / 80)$ were debrided early and late respectively $(p$-value $=0.05)($ Table 3$)$.
Table 2 Distribution of patients according to fracture characteristics

\begin{tabular}{|c|c|c|}
\hline Fracture characteristics & Frequency & Percentages \\
\hline \multicolumn{3}{|l|}{ Site of fracture } \\
\hline Femur & 31 & 21.7 \\
\hline Tibia & 66 & 46.1 \\
\hline Ankle & 5 & 3.5 \\
\hline Humerus & 17 & 11.9 \\
\hline Forearm & 19 & 13.3 \\
\hline Multiple & 5 & 3.5 \\
\hline \multicolumn{3}{|l|}{ Gustilo Anderson grade } \\
\hline I & 24 & 16.8 \\
\hline$\|$ & 92 & 63.3 \\
\hline$\| \mathrm{A}$ & 21 & 14.7 \\
\hline$\| \mathrm{II}$ & 5 & 3.5 \\
\hline IIIC & 1 & 0.7 \\
\hline \multicolumn{3}{|l|}{ Location of fracture } \\
\hline Proximal & 21 & 14.7 \\
\hline Mid-shaft & 57 & 39.9 \\
\hline Distal & 58 & 40.6 \\
\hline More than one location & 7 & 4.9 \\
\hline \multicolumn{3}{|l|}{ Affected limb } \\
\hline Right & 86 & 60.1 \\
\hline Left & 55 & 38.5 \\
\hline Bilateral & 1 & 1.4 \\
\hline \multicolumn{3}{|l|}{ Fracture pattern } \\
\hline Transverse & 57 & 39.9 \\
\hline Oblique & 46 & 32.1 \\
\hline Comminuted & 22 & 15.3 \\
\hline Spiral & 18 & 12.6 \\
\hline
\end{tabular}

\section{Treatment outcomes}

Surgical site infection

Out of 143 patients who underwent surgical debridement for open long bone fractures, nine (6.3 \%) developed SSI. There was more SSI among patients who were debrided late compared to those debrided early $(6 / 9$ versus $3 / 9) ; p$-value $=0.503$, $95 \%$ CI $1.62(0.33-$ 10.40) although the different was not statistically significant (Table 4).

Majority of patients with SSI were in Gustilo grade II (4, $44.4 \%)$, whereas Grade IIIA and IIIB had 3 (33.3 \%) and $2(22.2 \%)$ patients respectively. The mechanism of injury among patients with SSI were blunt injury in about $6(66.67 \%)$ and a combination of both blunt and penetrating injuries in $3(33.3 \%)$. Most patients with SSI had open fracture involving the tibia (8, $88.9 \%)$ whereas in one patient $(11.1 \%)$ humerus was involved. 
Table 3 Association of early versus delayed debridement with variables

\begin{tabular}{|c|c|c|c|c|}
\hline \multirow[t]{3}{*}{ Variable } & \multicolumn{2}{|c|}{$\begin{array}{l}\text { Surgical debridement } \\
N=143\end{array}$} & \multirow[t]{3}{*}{ Chi 2} & \multirow[t]{3}{*}{$p$ value } \\
\hline & Early (63) & Late (80) & & \\
\hline & n (\%) & n (\%) & & \\
\hline Median age ${ }^{a}$ & $32(23-41)$ & $35(27-42)$ & - & 0.4006 \\
\hline \multicolumn{5}{|l|}{ Sex } \\
\hline Female & $23(31.5)$ & $31(38.8)$ & \multirow[t]{2}{*}{0.0754} & \multirow[t]{2}{*}{0.784} \\
\hline Male & $40(63.5)$ & $49(61.2)$ & & \\
\hline \multicolumn{5}{|l|}{ Occupation } \\
\hline Students & $10(15.8)$ & $8(10.0)$ & \multirow[t]{7}{*}{-} & \multirow[t]{7}{*}{0.382} \\
\hline Peasants & $20(31.7)$ & $28(35.0)$ & & \\
\hline Driver & $0(0.0)$ & $3(3.7)$ & & \\
\hline Motorcycle rider & $7(11.1)$ & $12(15.0)$ & & \\
\hline Civil servants & $10(15.9)$ & $9(11.3)$ & & \\
\hline Businessman/women & $14(22.2)$ & $20(25)$ & & \\
\hline Others & $2(3.2)$ & $0(0.0)$ & & \\
\hline \multicolumn{5}{|l|}{ Cause of injury } \\
\hline RTA & $45(71.4)$ & $52(65.0)$ & \multirow[t]{4}{*}{-} & \multirow[t]{4}{*}{0.828} \\
\hline Falls & $9(14.3)$ & $13(16.3)$ & & \\
\hline Assaults & $8(12.7)$ & $12(15.0)$ & & \\
\hline Others & $1(1.6)$ & $3(3.75)$ & & \\
\hline \multicolumn{5}{|l|}{ Place of injury } \\
\hline Along road & $44(69.8)$ & $52(65.0)$ & \multirow[t]{5}{*}{-} & \multirow[t]{5}{*}{0.793} \\
\hline Residential area & $10(15.9)$ & $13(16.3)$ & & \\
\hline Home & $6(9.5)$ & $12(15.0)$ & & \\
\hline School & $2(3.2)$ & $1(1.2)$ & & \\
\hline Other places & $1(1.6)$ & $2(2.5)$ & & \\
\hline \multicolumn{5}{|l|}{ HIV Serostatus } \\
\hline Seropositive & $60(95.2)$ & 74 (92.5) & \multirow[t]{2}{*}{-} & \multirow[t]{2}{*}{0.379} \\
\hline Seronegative & $3(4.7)$ & $6(7.5)$ & & \\
\hline \multicolumn{5}{|l|}{ Mechanism of injury } \\
\hline Blunt injury & $35(55.6)$ & $38(47.5)$ & \multirow[t]{3}{*}{3.187} & \multirow[t]{3}{*}{0.203} \\
\hline Penetrating & $13(20.6)$ & $12(15)$ & & \\
\hline Both & $15(23.8)$ & $30(37.5)$ & & \\
\hline \multicolumn{5}{|l|}{ Site of open fracture } \\
\hline Femur & $16(25.4)$ & $15(18.8)$ & \multirow[t]{6}{*}{-} & \multirow[t]{6}{*}{0.136} \\
\hline Tibia & $27(42.9)$ & $39(48.8)$ & & \\
\hline Ankle & $0(0.0)$ & $5(6.25)$ & & \\
\hline Humerus & $9(14.3)$ & $8(10.0)$ & & \\
\hline Forearm & $7(11.1)$ & $12(15.0)$ & & \\
\hline Multiple sites & $4(6.4)$ & $1(1.3)$ & & \\
\hline Gustillo and Anderson gr & & & & \\
\hline । & 18 (28.6) & $6(7.5)$ & - & 0.05 \\
\hline$\|$ & $33(52.4)$ & $59(73.8)$ & & \\
\hline IIla & $9(14.3)$ & $12(15.0)$ & & \\
\hline
\end{tabular}

Table 3 Association of early versus delayed debridement with variables (Continued)

\begin{tabular}{|c|c|c|c|c|}
\hline$\| l l b$ & $2(3.2)$ & $3(3.8)$ & & \\
\hline IIIC & $1(1.6)$ & $0(0.0)$ & & \\
\hline \multicolumn{5}{|l|}{ Fracture location } \\
\hline Proximal & $10(15.9)$ & $11(13.8)$ & - & 0.865 \\
\hline Mid shaft & $26(41.2)$ & $31(38.8)$ & & \\
\hline Distal & $25(39.7)$ & $33(41.3)$ & & \\
\hline More than one location & $2(3.2)$ & $5(6.3)$ & & \\
\hline \multicolumn{5}{|l|}{ Fracture pattern } \\
\hline Transverse & $28(44.4)$ & $29(36.3)$ & - & 0.333 \\
\hline Comminuted & $6(9.5)$ & $16(20.0)$ & & \\
\hline Oblique & $20(31.8)$ & $26(32.5)$ & & \\
\hline Spiral & $9(14.3)$ & $9(11.3)$ & & \\
\hline \multicolumn{5}{|l|}{ Rank of surgeon } \\
\hline Specialist & $4(6.4)$ & $1(1.3)$ & - & 0.118 \\
\hline Resident/medical officer & $59(93.7)$ & $79(98.5)$ & & \\
\hline \multicolumn{5}{|l|}{ Skeletal stabilisation } \\
\hline Skeletal traction & $13(20.6)$ & $15(18.8)$ & - & 0.858 \\
\hline ORIF & $5(7.9)$ & $4(5.0)$ & & \\
\hline POP & $29(46.0)$ & $41(51.3)$ & & \\
\hline External fixation & $16(25.4)$ & $20(25.0)$ & & \\
\hline
\end{tabular}

\section{Length of hospital stay}

The overall median length of hospital stay (IQR) was 7 (5-10) days with the range from 3 to 35 days. The median LOS (IQR) of patients who had surgical debridement within $6 \mathrm{~h}$ and after $6 \mathrm{~h}$ of injury were $6(5-10)$ days and 7 (6-11.5) days respectively, $p$-value $=0.06$. The respective ranges were 3 to 35 days and 3 to 23 days.

\section{The bacterial isolates involved in surgical site infections} and their antimicrobial susceptibility patterns

Nine patients developed SSI resulting into 15 bacterial isolates on aerobic culture (five patients had single bacteria, two patients had two bacteria and two patients had three bacteria each). The most common bacteria was Pseudomonas aeruginosa 6 (40.0\%), followed by Escherichia coli 3 (20.0\%), Klebsiella pneumonia 3 (20.0\%), whereas Proteus mirabilis, Pantoea agglomerans and Staphylococcus aureus each constituted one isolate (6.6\%) (Table 5).

There was high level of resistance among tested Gram negative bacteria to ampicillin (100\%,8/8), trimethoprim sulphamethoxazole $(87.3 \%, 7 / 8)$ and ceftriaxone $(62.5 \%, 5 / 8)$. Low resistance to gentamicin $(14.3 \%, 2 /$ $14)$, ciprofloxacin $(14.3 \%, 2 / 14)$, cefepime $(0 \%)$ and meropenem $(9.1 \%, 1 / 11)$. Staphylococcus aureus isolate 
Table 4 Association between the timing of surgical debridement and the rate of surgical site infections

\begin{tabular}{llll}
\hline Timing of surgical debridement & \multicolumn{3}{l}{ Surgical site infections } \\
\cline { 2 - 4 } & $\begin{array}{l}\text { Present } \\
(\mathrm{n}, \%)\end{array}$ & $\begin{array}{l}\text { Absent } \\
(\mathrm{n}, \%)\end{array}$ & $\begin{array}{l}\text { Total } \\
(\mathrm{n}, \%)\end{array}$ \\
\hline Early ( $\leq 6$ h of injury) & $3(33.3)$ & $60(44.8)$ & $63(44.1)$ \\
Late (> 6 h of injury) & $6(66.7)$ & $74(55.2)$ & $80(55.9)$ \\
Total & $9(100.0)$ & $134(100.0)$ & $143(100)$ \\
\hline
\end{tabular}

Pearson's chi square $(X 2)=0.448, p$-value $=0.503$

was sensitive to all antimicrobial agents tested except for Trimethoprim sulphamethoxazole (Table 5).

\section{Discussion}

In this study, most of patients were youth in their most productive years and showed a male preponderance. Similar demographic observations were also reported by other authors $[2,6,7,25,26]$. The reason for male predominance in their peak productive age may be due to the fact that males are more mobile and actively involved in various activities including high risk activities.

Similar to other previous studies $[2,6,8,25,26]$, majority of injuries were due to RTA. This may be attributable to the legalization of motorcycles as a means of transport in Tanzania, emphasizing the need to have urgent interventions which are specifically aiming at reducing the occurrence of RTA and its related health impacts in this country. Interventional measures at both primary preventive level such as educating motorcyclists and their passengers on adherence to road safety rules and wearing protecting gears as well as secondary prevention such as timely medical and surgical management once individuals sustain injuries should be an enduring focus [7]. Most patients in this study sustained blunt injuries, which is comparable to another previous study in the same city [7], but contrary to another study where penetrating injuries predominated [25].

The anatomical relation of tibia, its subcutaneous orientation with precarious blood supply reiterated on its preponderance involvement in this and other studies $[1,27]$. In the present study, nearly two third of patients had Gustilo-Anderson grade II and this is similar to other studies $[16,18]$ but contrary to a study in Rwanda where Gustilo grade III was the most frequent grade [26]. Moreover, the present study showed a significant association of timing of debridement and GustiloAnderson classification with predominance of GustiloAnderson grade II.

Despite the prevailing conventional management based on the " 6 h rule" especially in developing countries [13],

Table 5 Bacteria isolates causing surgical site infections in patients with open fracture and their antimicrobial susceptibility patterns

\begin{tabular}{|c|c|c|c|c|c|c|c|c|c|c|c|}
\hline \multicolumn{12}{|l|}{ Gram negative bacteria: } \\
\hline \multirow[t]{2}{*}{ Bacterial isolates } & & & & \multicolumn{8}{|c|}{ Antimicrobial susceptibility patterns } \\
\hline & Study \# & AMP & SXT & GEN & $\mathrm{CIP}$ & FEP & TZP & CAZ & CTR & AM/C & MER \\
\hline Pseudomonas aeruginosa & 032 & NA & NA & $\mathrm{R}$ & $\mathrm{R}$ & $S$ & $S$ & S & NA & NA & S \\
\hline Escherichia coli & 037 & $\mathrm{R}$ & 1 & $S$ & S & $S$ & I & S & $\mathrm{R}$ & $\mathrm{R}$ & NT \\
\hline Klebsiella pneumoniae & 037 & $\mathrm{R}$ & $\mathrm{R}$ & S & S & $S$ & $\mathrm{~S}$ & S & $\mathrm{R}$ & $\mathrm{R}$ & NT \\
\hline Proteus mirabilis & 037 & $\mathrm{R}$ & S & $S$ & $S$ & $S$ & NT & S & S & $\mathrm{R}$ & NT \\
\hline Pseudomonas aeruginosa & 095 & NA & NA & S & S & NT & $S$ & $S$ & NA & NA & S \\
\hline Pseudomonas aeruginosa & 096 & NA & NA & $\mathrm{S}$ & S & NT & $\mathrm{S}$ & 1 & NA & NA & $S$ \\
\hline Pseudomonas aeruginosa & 099 & NA & NA & $S$ & S & NT & $\mathrm{S}$ & $S$ & NA & NA & S \\
\hline Escherichia coli & 103 & $\mathrm{R}$ & $\mathrm{R}$ & $S$ & S & $S$ & NT & $S$ & $S$ & $\mathrm{R}$ & $S$ \\
\hline Klebsiella pneumoniae & 103 & $\mathrm{R}$ & $\mathrm{R}$ & S & S & $S$ & NT & $S$ & S & S & S \\
\hline Pseudomonas aeruginosa & 110 & NA & NA & S & S & NT & $S$ & R & NA & NA & $S$ \\
\hline Pseudomonas aeruginosa & 115 & NA & NA & S & S & NT & S & $S$ & NA & NA & S \\
\hline Klebsiella pneumoniae & 141 & $\mathrm{R}$ & $\mathrm{R}$ & $\mathrm{R}$ & S & $S$ & $\mathrm{R}$ & $\mathrm{R}$ & $\mathrm{R}$ & $\mathrm{R}$ & S \\
\hline Escherichia coli & 141 & $\mathrm{R}$ & $\mathrm{R}$ & S & $\mathrm{R}$ & $S$ & $\mathrm{R}$ & $\mathrm{R}$ & $\mathrm{R}$ & $\mathrm{R}$ & $\mathrm{R}$ \\
\hline Pantoea agglomerans & 141 & $\mathrm{R}$ & $\mathrm{R}$ & S & S & NT & $\mathrm{R}$ & $\mathrm{R}$ & $\mathrm{R}$ & $\mathrm{R}$ & S \\
\hline \multicolumn{12}{|l|}{ Gram positive bacteria: } \\
\hline Bacterial Isolate & \# & FOX & SXT & GEN & CIP & ERY & CAD & VAN & & & \\
\hline Staphylococccus aureus & 115 & S & $\mathrm{R}$ & S & S & $S$ & $\mathrm{~S}$ & S & & & \\
\hline
\end{tabular}

AMP ampicillin, SXT trimethoprim-sulphamethoxazole, GEN gentamicin, CIP ciprofloxacin, FEP cefepime, TZP piperacillin-tazobactam, CAZ ceftazidime, CTR ceftriaxone, $A M C$ amoxycillin-clavulanate, MER meropenem, FOX cefoxitin, $E R Y$ erythromycin, $C A D$ clindamycin, $V A N$ vancomycin, $S$ sensitive; $R$ resistance, $I$ intermidiate, NA not applicable, NT not tested 
the universally acceptability of this strategy remains elusive. Some studies have shown evidence which advocate the fact that surgical debridement within $6 \mathrm{~h}$ may result into favorable outcomes [14, 26, 28-30]; where as others are not supporting timing of debridement as the sore dependent factor predicting favorable outcomes but rather associate the outcomes with the injury severity as per Gustilo-Anderson classification and initial basic interventions [14, 16-18, 20, 31-33]. In the present study, more than half of patients presented late and had surgical debridement done more than six hours after the injury. Late surgical debridement can be explained by late presentation to the hospital due to logistical constraints and poor general condition of the patients that requires pre-operative resuscitation. The overall rate of SSI among the study population (6.3\%) is low and comparable to other studies from USA, Egypt, Canada, UK and Germany where the rates were 14, 11.6, 9.3, 8.5 and $6.6-8 \%$ respectively $[15,18,27,30,34]$. The slightly higher infection rates in these countries as opposed to the present study may be related to prolonged follow up period which ranged from 3 to 36 months. Moreover, the rate in the present study is significantly lower than another study in the same hospital where wound sepsis accounted for approximately $22 \%$ connoting improvement in the infection control and prevention for the past three years [35]. The differences may be associated with the environmental conditions where accidents occurred, timing of the interventions as well as surgical techniques in these countries. The renovated accident and emergence department and timely surgical intervention upon arrival of these patients may partly explain the low rate of SSI at BMC in the present study.

In the present study, more cases of SSI were found among patients who had surgical debridement late compare to those who were debrided early (7.5 \% versus $4.8 \%)$ although the difference was not statistically significant and is similar to other studies in USA and UK where the respective proportions were $38 \%$ versus $7 \%$ [14], $25 \%$ versus $12 \%$ [30] and $10.8 \%$ versus $10.1 \%$ [36]. This could be attributed to the fact that, delay in prompt management among these patients may create chances of exposure of the fracture site to microbial flora (endogenous) and pathogens (exogenous) leading to SSI. The low infection rates in both groups reiterate the fact that when surgical intervention are promptly done, the outcome may be favorable irrespective of the timing of debridement $[15,18,31]$. Nevertheless, a paradoxical result was found in a study conducted in Egypt where there were of more cases of SSI in the early group (7/12) compared to the late group (5/12) [18]. The length of hospital stay was also slightly more in the late group compared to the early group, although the difference was not statistically significant. In the light of these findings on the outcomes; both groups deserves equal attention so as to reduce financial and other logistical implications related to SSI and longer LOS [32].

In the present study, Gram negative bacteria predominated with Pseudomonas aeruginosa being leading bacterial species. Similarly other studies have shown the predominance of Gram negative bacteria [37-39] and of recent Pseudomonas aeruginosa is reported at BMC as the commonest bacteria colonizing patients with chronic lower limb ulcers [40]; connoting the possibility of nosocomial transmission if stringent infection control and prevention are not adhered in this setting. Similar to another study done in Uganda, the majority of isolates showed high sensitivities to less used antimicrobial agents (gentamicin, ciprofloxacin, cefepine and meropenem) as opposed to commonly used agents (ampicillin, trimethoprim sulphamethoxazole and ceftriaxone) exemplifying the need to have laboratory guided antimicrobial therapy in this setting [38].

\section{Study limitation}

The follow up of patients was limited to only one months; thus this could have underestimated the incidence of SSI. Anaerobic culture was not done as it is apparently not done at BMC or CUHAS.

\section{Conclusions}

Open long bone fracture injuries are common at BMC, with majority of these injuries being attributed to RTA. The risk of developing SSI was low at BMC and comparable to many other countries; with Pseudomonas aeruginosa being commonly implicated causative agent. Despite the fact that there was no statistical significant difference between early versus delayed debrided groups on SSI and LOS stays; the need for prompt surgical intervention in both groups should be an enduring focus to maintain these favorable outcomes.

In the light of this, a long term prospective cohort study with a larger sample size would be of interest to further delineate the predictors of outcome among patients with open long bone fractures as well as the role of bacterial species for effective antimicrobial policy formulation.

\section{Acknowledgements}

Authors are sincerely thankful for patients who were involved in this study as well as cordial support from the staffs in the Departments of General Surgery, Orthopedic \& Traumatology and Microbiology \& Immunology of BMC and CUHAS.

\section{Authors' contributions}

NJ, JS, RMD, SEM and JMG: conceived, designed and executed the study; NJ, RMD, IHN and JMG: participated in patients management; NJ and NM: participated in sample collection; NM, JS and SEM: participated in laboratory sample analysis; NJ, NM, JS and IHN: participated in data analysis; JS wrote the first draft of the manuscript which was critically revised by all authors. All authors read and approved the final manuscript. 


\section{Competing interests}

The authors declare that they have no competing interests.

\section{Author details}

'Department of Surgery, Catholic University of Health and Allied Sciences, P.O.Box 1464, Mwanza, Tanzania. ${ }^{2}$ Department of Surgery, Bugando Medical Centre, P.O.Box 1370, Mwanza, Tanzania. ${ }^{3}$ Department of Microbiology and Immunology, Catholic University of Health and Allied Sciences, P.O.Box 1464, Mwanza, Tanzania.

\section{Received: 6 September 2015 Accepted: 16 June 2016} Published online: 04 July 2016

\section{References}

1. Court-Brown CM, Rimmer S, Prakash U, McQueen MM. The epidemiology of open long bone fractures. Injury. 1998;29(7):529-34.

2. Demyttenaere SV, Nansamba C, Nganwa A, Mutto M, Lett R, Razek T. Injury in Kampala, Uganda: 6 years later. Can J Surg. 2009;52(5):E146-50.

3. Arruda LRP, Silva MAC, Malerba FG, Fernandes MC, Turíbio FM, Matsumoto $\mathrm{MH}$. Open fractures: prospective and epidemiological study. Acta Ortop Bras. 2009;17(6):326-30.

4. Babhulkar S, Raza HK. Open fractures. Indian J Orthop. 2008:42(4):365-7.

5. Museru L, Leshabari M, Grob U, Lisokotola L. The pattern of injuries seen in patients in the orthopaedic/trauma wards of Muhimbili Medical Centre. East Cent Afr J Surg. 1998;4(1):15-21

6. Mutasingwa DR, Aaro LE. Injury registry in developing country. A study based on patients record from four hospitals in Dare Salaam, Tanzania. Cent Afr J Med. 2001;47(8):203-9.

7. Chalya PL, Mabula JB, Ngayomela IH, Kanumba ES, Chandika AB, Giiti G, Mawala B, Balumuka DD. Motorcycle injuries as an emerging public health problem in Mwanza City, north-western Tanzania. Tanzan J Health Res. 2010; 12(4):214-21.

8. Chalya PL, Gilyoma JM, Dass RM, McHembe MD, Matasha M, Mabula JB, Mbelenge N, Mahalu W. Trauma admissions to the intensive care unit at a reference hospital in Northwestern Tanzania. Scand J Trauma Resusc Emerg Med. 2011;19:61

9. Nwadinigwe CU, Onyemaechi NC. Lethal outcome and time to death in injured hospitalised patients. Orient J Med. 2005;17(1):28-33.

10. Gustilo RB, Anderson JT. Prevention of infection in the treatment of one thousand and twenty-five open fractures of long bones: retrospective and prospective analyses. J Bone Joint Surg Am. 1976;58(4):453-8.

11. Nanchahal J, Nayagam S, Khan U, Moran C, Barrett S, Sanderson F, Pallister I. The Standards for the Management of Open Fractures of the Lower Limb. In: British Association of Plastic, Reconstructive and Aesthetic Surgeons. London: Royal Society of Medicine Press Ltd; 2009.

12. Griffin M, Malahias M, Khan W. Hindocha S. Update on the management of open lower limb fractures. Open Orthop J. 2012;6:571-7.

13. Gustilo RB, Merkow RL, Templeman D. The management of open fractures. J Bone Joint Surg Am. 1990;72(2):299-304

14. Kindsfater $\mathrm{K}$, Jonassen EA. Osteomyelitis in grade II and III open tibia fractures with late debridement. J Orthop Trauma. 1995;9(2):121-7.

15. Harley BJ, Beaupre LA, Jones CA, Dulai SK, Weber DW. The effect of time to definitive treatment on the rate of nonunion and infection in open fractures. J Orthop Trauma. 2002;16(7):484-90.

16. Khatod M, Botte MJ, Hoyt DB, Meyer RS, Smith JM, Akeson WH. Outcomes in open tibia fractures: relationship between delay in treatment and infection. J Trauma. 2003:55(5):949-54.

17. Pollak AN, Jones AL, Castillo RC, Bosse MJ, MacKenzie EJ. The relationship between time to surgical debridement and incidence of infection after open high-energy lower extremity trauma. J Bone Joint Surg Am. 2010;92(1):7-15.

18. Kamat AS. Infection rates in open fractures of the tibia: is the 6-hour rule fact or fiction? Adv Orthop. 2011;2011:943495.

19. Patzakis MJ, Wilkins J. Factors influencing infection rate in open fracture wounds. Clin Orthop Relat Res. 1989:243:36-40

20. Enninghorst N, McDougall D, Hunt JJ, Balogh ZJ. Open tibia fractures: timely debridement leaves injury severity as the only determinant of poor outcome. J Trauma. 2011;70(2):352-6. discussion 356-357.

21. NACP. National quidelines for the management of HIV and AIDS. Ministry of Health Of And Social Welfare. The United Republic of Tanzania. 4th ed. National AIDS Control Program. Dar-Es-Salaam. United Republic of Tanzania. 2012
22. Mangram AJ, Horan TC, Pearson ML, Silver LC, Jarvis WR. Guideline for prevention of surgical site infection, 1999. Centers for Disease Control and Prevention (CDC) Hospital Infection Control Practices Advisory Committee. Am J Infect Control. 1999:27(2):97-132. quiz 133-134; discussion 196.

23. Koneman EW, Allen SD, Janda WM, Schreckenberger PC, Winn WC. Color atlas and textbook of diagnostic microbiology. 5th ed. Philadelphia, Pa: Lippincott, Williams \& Wilkins Publishers; 1997.

24. CLSI. Perfomance standards for antimicrobial susceptibility testing; twenty first information supplement. vol. CLSI document M100-S21. Wayne: Clinical and Laboratory Standards Institute; 2011.

25. Thanni LO, Kehinde OA. Trauma at a Nigerian teaching hospital: pattern and docu-mentation of presentation. Afr Health Sci. 2006;6(2):104-7.

26. Twagirayezu E, Dushimiyimana J, Bonane A. Open fractures I Rwanda: the Kigali experience. East Cent Afr J Surg. 2008;13(1):77-83.

27. Naique SB, Pearse M, Nanchahal J. Management of severe open tibial fractures: the need for combined orthopaedic and plastic surgical treatment in specialist centres. J Bone Joint Surg Br. 2006;88(3):351-7.

28. Pollak AN. Timing of debridement of open fractures. J Am Acad Orthop Surg. 2006;14(10 Spec No):S48-51.

29. Robson MC, Duke WF, Krizek TJ. Rapid bacterial screening in the treatment of civilian wounds. J Surg Res. 1973;14(5):426-30.

30. Kreder HJ, Armstrong P. A review of open tibia fractures in children. J Pediatr Orthop. 1995;15(4):482-8,

31. Ashford RU, Mehta JA, Cripps R. Delayed presentation is no barrier to satisfactory outcome in the management of open tibial fractures. Injury. 2004;35(4):411-6.

32. Bednar DA, Parikh J. Effect of time delay from injury to primary management on the incidence of deep infection after open fractures of the lower extremities caused by blunt trauma in adults. J Orthop Trauma. 1993;7(6):532-5.

33. Werner CM, Pierpont Y, Pollak AN. The urgency of surgical debridement in the management of open fractures. J Am Acad Orthop Surg. 2008;16(7):369-75.

34. Carsenti-Etesse H, Doyon F, Desplaces N, Gagey O, Tancrede C, Pradier C, Dunais B, Dellamonica P. Epidemiology of bacterial infection during management of open leg fractures. Eur J Clin Microbiol Infect Dis. 1999; 18(5):315-23.

35. Chalya PL, Mabula JB, Dass RM, Mbelenge N, Ngayomela IH, Chandika AB, Gilyoma JM. Injury characteristics and outcome of road traffic crash victims at Bugando Medical Centre in Northwestern Tanzania. J Trauma Manag Outcomes. 2012:6(1):1.

36. Spencer J, Smith A, Woods D. The effect of time delay on infection in open long-bone fractures: a 5-year prospective audit from a district general hospital. Ann R Coll Surg Engl. 2004;86(2):108-12.

37. Merritt K. Factors increasing the risk of infection in patients with open fractures. J Trauma, 1988:28(6):823-7.

38. Seni J, Najjuka CF, Kateete DP, Makobore P, Joloba ML, Kajumbula H, Kapesa A, Bwanga F. Antimicrobial resistance in hospitalized surgical patients: a silently emerging public health concern in Uganda. BMC Res Notes. 2013;6:298.

39. Seekamp A, Köntopp H, Schandelmaier P, Krettek C, Tscherne H. Bacterial cultures and bacterial infection in open fractures. Eur J Trauma. 2000;26(3):131-8.

40. Moremi N, Mushi MF, Fidelis M, Chalya P, Mirambo M, Mshana SE. Predominance of multi-resistant gram-negative bacteria colonizing chronic lower limb ulcers (CLLUs) at Bugando Medical Center. BMC Res Notes. 2014;7:211.

\section{Submit your next manuscript to BioMed Central and we will help you at every step:}

- We accept pre-submission inquiries

- Our selector tool helps you to find the most relevant journal

- We provide round the clock customer support

- Convenient online submission

- Thorough peer review

- Inclusion in PubMed and all major indexing services

- Maximum visibility for your research

Submit your manuscript at www.biomedcentral.com/submit 